\title{
Effect of n-3 Ployunsaturated Fatty Acid Supplementation on Pregnancy Outcomes: A Systematic Review and Meta- Analysis
}

\author{
Yingying Hao \\ Shengjing Hospital of China Medical University \\ Xiaoshi Sun \\ Shengjing Hospital of China Medical University \\ Ningning Wen \\ Shengjing Hospital of China Medical University \\ Hong Li ( $\nabla$ lh7710@sina.com) \\ China Medical University https://orcid.org/0000-0001-8742-9405
}

\section{Research}

Keywords: $n-3$ polyunsaturated fatty acid, pregnancy outcome, meta-analysis

Posted Date: February 26th, 2021

DOI: https://doi.org/10.21203/rs.3.rs-248883/v1

License: (c) (i) This work is licensed under a Creative Commons Attribution 4.0 International License. Read Full License 


\section{Abstract}

Background: The goal of this study was to review relevant studies in order to determine the effect of n-3 polyunsaturated fatty acid (n-3 PUFA) supplementation on pregnancy outcomes based on eligible randomized controlled trails (RCTs).

Method: Qualified studies were searched by keywords in PubMed, Cochrane and Embase. Studies from other pertinent sources were also reviewed, RCT studies published before January 2021 were reviewed. For each study, we assessed and synthesized the outcomes by relative risk (RR) or weighted mean difference (WMD) combined with $95 \%$ confidence interval $(95 \% \mathrm{Cl})$.

Result: We included 29 studies with 5623 patients. Compared with the control group, n-3 PUFA significantly decreased the incidence of preterm delivery (PD) (RR: $0.898,95 \% \mathrm{Cl}: 0.819 \sim 0.984$ ), low birthweight (RR: 0.797, 95\%Cl: 0.655 0.970), and preeclampsia (RR: 0.814, 95\%Cl: 0.687 0.966); increased the birth weight (WMD: 99.340, 95\%Cl: 10.503 188.177) and birth length (WMD: $0.449,95 \% \mathrm{Cl}: 0.236 \sim 0.663$ ). There was no significant difference in PIH, IUIG, early PD, antihypertensive therapy, gestational diabetes and head circumference at birth between the two groups.

Conclusion: The available evidence shows that n-3 PUFA is not beneficial in reducing the incidence of maternal pregnancy outcomes such as gestational diabetes mellitus and hypertension, but it is beneficial to neonatal health.

\section{Background}

Fat is very important for human nutrition. Fatty acids composed of fat can be divided into saturated and unsaturated fatty acids according to their different structures. Unsaturated fatty acids can be further divided into mono- and polyunsaturated fatty acids (PUFA). Long-chain PUFA (n-3 PUFA) cannot be synthesized in the human body and must be obtained from food. The fetus receives nutrients from the mother through the placenta[1-4]. Fatty acids obtained from the mother are influenced by the composition of the mother's diet. The placenta also plays an important role in the transport of fatty acids from the mother to the fetus. Maternal preeclampsia is often associated with fetal growth restriction and early placental development defects. The placenta is one of the main sources of lipid peroxidation, and n3 PUFA plays a potential important regulatory role in the regulation of fat metabolism in the placenta and fetus. At the same time, n-3PUFA, especially docosahexaenoic acid (DHA), is an important component of the cellular membranes of the retina and the cerebral cortex, and plays a definite role in promoting the development of vision and the central nervous system[5-7]. In addition, n-3 PUFA is essential fatty acids for the human body, and since the mid 20th century, it has been found to help reduce cardiovascular disease morbidity and mortality. Extensive research has been carried out on n-3 PUFA and has shown that it has a wide range of biological characteristics and functions, and plays an important role not only in regulating lipid metabolism but also in inflammation, and it is very important to brain development and function of the brain[8, 9]. Based on reviewing qualified randomized controlled trials (RCTs), the aim of this study was to explore the effect of n-3 PUFA supplementation on pregnancy outcomes.

\section{Methods}

\section{Search strategy}

The data of clinical indexes about the effect of n-3 PUFA supplementation on pregnancy outcomes based on qualified RCTs has been obtained from the included studies. In the databases (Cochrane, PubMed, and Embase), all the relevant RCTs before January 2021 were reviewed. In the qualified RCTs, the references were also reviewed. The key words included fatty acids, omega-3, n-3 polyunsaturated fatty acid, PUFA, n-3 PUFA, alpha-linolenic acid, fish oil, EPA, DHA, ALA, pregnancy, random, randomized control study, randomized controlled trial, RCT. All the above key words were 
combined with "AND" or "OR". Literature retrieval was done by two investigators independently. However, when there was disagreement, a third investigator was involved to make a decision.

Following the PICOS principle, the key search terms included (P, participants) pregnant women; (I, interventions) pregnant women in the treatment group treated by n-3 PUFA, pregnant women in the control group treated by standard care, normal diet, olive oil or placebo; (C/O, comparison/outcome) the comparison of the pregnancy outcome; (S, study design) designed as RCT.

\section{Study selection criteria}

Included studies should meet all the following inclusion criteria: (1) the study was designed as a RCT; (2) the subjects were pregnant women; (3) patients were treated by n-3 PUFA; 4) articles were published in English or Chinese.

If the studies met any of the following exclusion criteria, it was excluded: (1) duplicate articles or similar results; (2) obvious data errors; (3) cohort study, case-control, case analysis, theoretical research or reviews, guideline, reports, metaanalyses, or other forms of research or comments that were not designed as RCT; (4) data irrelevant to this study.

The studies were reviewed by two investigators independently to determine whether the included studies met the inclusion criteria and did not meet the exclusion criteria, with a third investigator to resolve any disagreement.

\section{Data extraction and quality assessment}

In all the included RCTs, two categories of data (the basic characteristics of articles and the data of main clinical indexes) were extracted. The basic characteristics of articles contained authors' names, publication year, detailed interventions, sample size, age and gestational age. The main clinical indexes contained PD, preeclampsia, pregnancyinduced hypertension (PIH), low birthweight, intrauterine growth retardation (IUIG), early PD, anti-hypertensive therapy, gestational diabetes, and body length, body weight and head circumference at birth. The Jadad scoring checklist was used to appraise the quality of involved studies. We evaluated all the RCTs from the five items: statement of randomization; appropriateness of generating randomized sequence; use of double blinding; description of double blinding method; detail of withdrawals and dropouts. Studies with a score of less than 3 indicated low quality and high bias risk, studies with a score exceeding 3 indicated high quality. Data extraction was done by two investigators independently. However, when there was disagreement, a third investigator was involved to make a decision.

\section{Statistical Analysis}

STATA v10.0 (TX, USA) was used to conduct all the data analysis. The heterogeneity of the included RCTs were assessed by chi-squared and $\mathrm{I}^{2}$ tests, and the fixed-effects or random-effect analysis models were selected by the above results. When the included RCTs were of high heterogeneity (the chi-squared $\mathrm{P} \leq 0.05$ and an $\mathrm{I}^{2}>50 \%$ ), we selected the randomeffects model to analyze the indexes. When the included RCTs were of acceptable heterogeneity (the chi-squared P $>0.05$ and an $I^{2} \leq 50 \%$ ), we selected the fixed-effects model to analyze the indexes. Mean \pm standard deviation was used to describe continuous variables, which were then analyzed by the weighted mean difference (WMD). Percentage was used to describe categorical variables, which were analyzed by relative risk (RR). Body length, body weight and head circumference at birth were analyzed by WMD while other indexes were analyzed by RR.

\section{Results}

\section{Overview of the Included Studies}

At last, 649 articles were identified through search using initial keywords. After reviewing the titles and abstracts, we excluded 562 articles. The remaining 87 articles were evaluated by reading the full text, and then 73 articles were 
excluded using the selection criteria. The studies were excluded for the following reasons: no qualified studies (21), lack of clinical outcomes (27), review or theory research (8), and non-RCT studies (17). Finally, 14 studies[8, 10-22] with 14090 pregnant women that met the inclusion criteria were included in this meta-analysis. Article screening process is presented in Fig. 1. The basic information of each study is summarized in Table 1. The main Jadad score of the included studies was 4.35 , and the main score was higher than 3, indicating high-quality of the 14 included RCTs. 
Table 1

The basic characteristics description of included studies

\begin{tabular}{|c|c|c|c|c|c|c|c|c|c|}
\hline \multirow[t]{2}{*}{ Study } & \multicolumn{2}{|l|}{ Interventions } & \multicolumn{2}{|c|}{$\begin{array}{l}\text { No. of } \\
\text { patients }\end{array}$} & \multicolumn{2}{|c|}{ Age (year) } & \multicolumn{2}{|c|}{$\begin{array}{l}\text { Gestational } \\
\text { age (week) }\end{array}$} & \multirow[t]{2}{*}{$\begin{array}{l}\text { Jadad } \\
\text { score }\end{array}$} \\
\hline & $\mathrm{T}$ & C & $\mathrm{T}$ & C & $\mathrm{T}$ & C & $\mathrm{T}$ & C & \\
\hline $\begin{array}{l}\text { Sjrirhr F. } \\
\text { Olsen } 2000 \text { a }\end{array}$ & \multirow{4}{*}{$\begin{array}{l}\text { four capsules of } \\
\text { either oil were } \\
\text { given per day, fish } \\
\text { oil } 2.7 \mathrm{~g}(1.3 \mathrm{~g} \\
\text { eicosapentaenoic } \\
\text { acid and } 0-9 \mathrm{~g} \\
\text { docosahexaenoic } \\
\text { acid) }\end{array}$} & \multirow{4}{*}{$\begin{array}{l}\text { four capsules of } \\
\text { olive oil were } \\
\text { given per day }\end{array}$} & 110 & 122 & 29.3 & 30 & $\begin{array}{l}131.8 \\
\text { days }\end{array}$ & $\begin{array}{l}130.5 \\
\text { days }\end{array}$ & 5 \\
\hline $\begin{array}{l}\text { Sjrirhr F. } \\
\text { Olsen } 2000 \text { b }\end{array}$ & & & 141 & 139 & 30 & 29 & $\begin{array}{l}128.1 \\
\text { days }\end{array}$ & $\begin{array}{l}131.2 \\
\text { days }\end{array}$ & 5 \\
\hline $\begin{array}{l}\text { Sjrirhr F. } \\
\text { Olsen } 2000 \text { c }\end{array}$ & & & 184 & 202 & 30.3 & 28.9 & $\begin{array}{l}129.6 \\
\text { days }\end{array}$ & $\begin{array}{l}132.1 \\
\text { days }\end{array}$ & 5 \\
\hline $\begin{array}{l}\text { Sjrirhr F. } \\
\text { Olsen } 2000 \mathrm{~d}\end{array}$ & & & 289 & 290 & 30.2 & 30.7 & $\begin{array}{l}141.5 \\
\text { days }\end{array}$ & $\begin{array}{l}141.5 \\
\text { days }\end{array}$ & 5 \\
\hline $\begin{array}{l}\text { Sjrirhr F. } \\
\text { Olsen } 2000 \text { e }\end{array}$ & \multirow{2}{*}{$\begin{array}{l}\text { nine capsules of } \\
\text { either oil were } \\
\text { given, fish oil } 6.1 \mathrm{~g} \\
(2.9 \mathrm{~g} \\
\text { eicosapentaenoic } \\
\text { acid and } 2-1 \mathrm{~g} \\
\text { docosahexaenoic } \\
\text { acid) per day }\end{array}$} & \multirow[t]{2}{*}{$\begin{array}{l}\text { nine capsules of } \\
\text { olive oil per day }\end{array}$} & 44 & 35 & 32.1 & 32.9 & $\begin{array}{l}231.9 \\
\text { days }\end{array}$ & $\begin{array}{l}219.6 \\
\text { days }\end{array}$ & 5 \\
\hline $\begin{array}{l}\text { Sjrirhr F. } \\
\text { Olsen } 2000 \mathrm{f}\end{array}$ & & & 36 & 37 & 29.3 & 29.8 & $\begin{array}{l}227.1 \\
\text { days }\end{array}$ & $\begin{array}{l}231.2 \\
\text { days }\end{array}$ & 5 \\
\hline $\begin{array}{l}\text { Cornelius M. } \\
\text { Smuts } 2003\end{array}$ & $\begin{array}{l}\text { docosahexaenoic } \\
\text { acid-enriched eggs } \\
\text { (mean of } 133 \mathrm{mg} \\
\text { of } \\
\text { docosahexaenoic } \\
\text { acid per egg) }\end{array}$ & $\begin{array}{l}\text { ordinary eggs } \\
\text { (mean of } 33 \mathrm{mg} \\
\text { of } \\
\text { docosahexaenoic } \\
\text { acid } \\
\text { per egg) }\end{array}$ & 142 & 149 & 21.7 & 21.6 & 26 & 26.1 & 5 \\
\hline $\begin{array}{l}\text { Shao J Zhou } \\
2012\end{array}$ & $\begin{array}{l}\text { DHA-enriched fish } \\
\text { oil }(800 \mathrm{mg} / \mathrm{d})\end{array}$ & $\begin{array}{l}\text { vegetable oil } \\
\text { capsules without } \\
\text { DHA }\end{array}$ & 1197 & 1202 & 28.9 & 28.9 & 19 & 19 & 5 \\
\hline $\begin{array}{l}\text { Sjurdur F. } \\
\text { Olsen } 1990 \mathrm{a}\end{array}$ & \multirow{2}{*}{$\begin{array}{l}\text { dietary } \\
\text { supplement } \\
\text { containing } \\
\text { vitamins, minerals, } \\
\text { and halibut liver } \\
\text { oil }\end{array}$} & \multirow[t]{2}{*}{$\begin{array}{l}\text { did not receive } \\
\text { any supplement }\end{array}$} & 1530 & 1512 & - & - & - & - & 3 \\
\hline $\begin{array}{l}\text { Sjurdur F. } \\
\text { Olsen } 1990 \text { b }\end{array}$ & & & 980 & 999 & - & - & - & - & 3 \\
\hline $\begin{array}{l}\text { H. J. HUISJE } \\
1994\end{array}$ & $\begin{array}{l}3 \mathrm{~g} \\
\text { eicosapentaenoic } \\
\text { acid daily }\end{array}$ & placebo & 32 & 31 & - & - & - & - & 3 \\
\hline $\begin{array}{l}\text { J. L. Onwude } \\
1995\end{array}$ & $\begin{array}{l}2.7 \mathrm{~g} \text { of MaxEpa } \\
\text { daily ( } 1.62 \mathrm{~g} \text { of } \\
\text { eicosapentaenoic } \\
\text { acid and } 1.08 \mathrm{~g} \text { of } \\
\text { docosahexaenoic } \\
\text { acid) }\end{array}$ & placebo & 113 & 119 & $\begin{array}{l}18- \\
39\end{array}$ & $\begin{array}{l}16- \\
40\end{array}$ & 24 & 24.4 & 3 \\
\hline $\begin{array}{l}\text { Jannie Dalby } \\
\text { Salvig } 1996 \\
\text { a }\end{array}$ & $\begin{array}{l}\text { fish oil }(2-7 \mathrm{~g} / \text { day } \\
\text { n-3 fatty acids } \\
(\text { Pikasol }))\end{array}$ & olive oil & 266 & 136 & 29.4 & 29.7 & - & - & 4 \\
\hline $\begin{array}{l}\text { Jannie Dalby } \\
\text { Salvig } 1996 \\
\text { b }\end{array}$ & $\begin{array}{l}\text { fish oil }(2-7 \mathrm{~g} / \text { day } \\
\text { n-3 fatty acids } \\
\text { (Pikasol)) }\end{array}$ & no oil & 266 & 131 & 29.4 & 29.1 & - & - & 4 \\
\hline
\end{tabular}




\begin{tabular}{|c|c|c|c|c|c|c|c|c|c|}
\hline \multirow[t]{2}{*}{ Study } & \multicolumn{2}{|l|}{ Interventions } & \multicolumn{2}{|c|}{$\begin{array}{l}\text { No. of } \\
\text { patients }\end{array}$} & \multicolumn{2}{|c|}{ Age (year) } & \multicolumn{2}{|c|}{$\begin{array}{l}\text { Gestational } \\
\text { age (week) }\end{array}$} & \multirow[t]{2}{*}{$\begin{array}{l}\text { Jadad } \\
\text { score }\end{array}$} \\
\hline & $\mathrm{T}$ & C & $\mathrm{T}$ & C & $\mathrm{T}$ & C & $\mathrm{T}$ & C & \\
\hline $\begin{array}{l}\text { Arminda } \\
\text { D'Almeida } \\
1992 \text { a }\end{array}$ & $\begin{array}{l}\text { Evening Primrose } \\
\text { Oil (Gamma } \\
\text { Linolenic Acid) } \\
\text { and Fish Oil } \\
\text { (Eicosapentaenoic } \\
\text { + Docahexaenoic } \\
\text { Acid) }\end{array}$ & Magnesium & 50 & 50 & - & - & - & - & 3 \\
\hline $\begin{array}{l}\text { Arminda } \\
\text { D'Almeida } \\
1992 \text { b }\end{array}$ & $\begin{array}{l}\text { Evening Primrose } \\
\text { Oil (Gamma } \\
\text { Linolenic Acid) } \\
\text { and Fish Oil } \\
\text { (Eicosapentaenoic } \\
\text { + Docahexaenoic } \\
\text { Acid) }\end{array}$ & placebo & 50 & 50 & - & - & - & - & 3 \\
\hline $\begin{array}{l}\text { Spencer G. } \\
\text { Kuper } 2017 \text { a }\end{array}$ & $\begin{array}{l}1200 \mathrm{mg} \\
\text { eicosapentaenoic } \\
\text { acid (EPA, 20:5n-3) } \\
\text { and } 800 \mathrm{mg} \\
\text { docosahexaenoic } \\
\text { acid (DHA, 22:6n- } \\
3 \text { ) for a total of } \\
2000 \mathrm{mg} \text { of } \\
\text { omega-3 long- } \\
\text { chain } \\
\text { polyunsaturated } \\
\text { fatty acids daily }\end{array}$ & placebo & 64 & 72 & 26 & 25.4 & 19.9 & 19.3 & 5 \\
\hline $\begin{array}{l}\text { Spencer G. } \\
\text { Kuper } 2017 \text { b }\end{array}$ & $\begin{array}{l}1201 \mathrm{mg} \\
\text { eicosapentaenoic } \\
\text { acid (EPA, 20:5n-3) } \\
\text { and } 800 \text { mg } \\
\text { docosahexaenoic } \\
\text { acid (DHA, 22:6n- } \\
\text { 3) for a total of } \\
2000 \text { mg of } \\
\text { omega-3 long- } \\
\text { chain } \\
\text { polyunsaturated } \\
\text { fatty acids daily }\end{array}$ & placebo & 370 & 345 & 28.1 & 28 & 19.4 & 19.6 & 5 \\
\hline $\begin{array}{l}\text { Margaret } \\
\text { Harper } 2010\end{array}$ & $\begin{array}{l}\text { daily omega-3 } \\
\text { supplement }(1,200 \\
\text { mg } \\
\text { eicosapentaenoic } \\
\text { acid and } 800 \text { mg } \\
\text { docosahexaenoic } \\
\text { acid) }\end{array}$ & placebo & 434 & 418 & 28 & 27 & 32 & 31 & 5 \\
\hline $\begin{array}{l}\text { Cornelius M. } \\
\text { Smuts } 2003 \\
\text { a }\end{array}$ & $\begin{array}{l}\text { high-DHA hen } \\
\text { eggs (135 mg } \\
\text { DHA/egg) }\end{array}$ & $\begin{array}{l}\text { ordinary eggs (18 } \\
\text { mg DHA/egg) }\end{array}$ & 18 & 19 & 19.9 & 24.8 & 26.1 & 26.7 & 4 \\
\hline $\begin{array}{l}\text { Cornelius M. } \\
\text { Smuts } 2003 \\
\text { b }\end{array}$ & $\begin{array}{l}\text { high-DHA hen } \\
\text { eggs (135 mg } \\
\text { DHA/egg) }\end{array}$ & low egg & 18 & 16 & 19.9 & 21.3 & 26.1 & 27 & 4 \\
\hline $\begin{array}{l}\text { Cornelius M. } \\
\text { Smuts } 2003 \\
\text { c }\end{array}$ & $\begin{array}{l}\text { ordinary eggs (18 } \\
\text { mg DHA/egg) }\end{array}$ & low egg & 19 & 16 & 24.8 & 21.3 & 26.7 & 27 & 4 \\
\hline
\end{tabular}




\begin{tabular}{|c|c|c|c|c|c|c|c|c|c|}
\hline \multirow[t]{2}{*}{ Study } & \multicolumn{2}{|l|}{ Interventions } & \multicolumn{2}{|c|}{$\begin{array}{l}\text { No. of } \\
\text { patients }\end{array}$} & \multicolumn{2}{|c|}{ Age (year) } & \multicolumn{2}{|c|}{$\begin{array}{l}\text { Gestational } \\
\text { age (week) }\end{array}$} & \multirow[t]{2}{*}{$\begin{array}{l}\text { Jadad } \\
\text { score }\end{array}$} \\
\hline & $\mathrm{T}$ & C & $\mathrm{T}$ & C & $\mathrm{T}$ & C & $\mathrm{T}$ & C & \\
\hline \multirow[t]{2}{*}{$\begin{array}{l}\text { Susan E } \\
\text { Carlson } 2013\end{array}$} & $\begin{array}{l}600 \mathrm{mg} / \mathrm{d} \text { of the } \\
\text { n23 LCPUFA }\end{array}$ & placebo & 178 & 172 & 25.3 & 24.8 & - & - & 5 \\
\hline & $\begin{array}{l}\text { docosahexaenoic } \\
\text { acid (DHA) }\end{array}$ & & & & & & & & \\
\hline $\begin{array}{l}\text { Ellen L. } \\
\text { Mozurkewich } \\
2013 \text { a }\end{array}$ & $\begin{array}{l}\text { EPA-rich fish oil } \\
\text { (1060 mg EPA } \\
\text { plus } 274 \mathrm{mg} \text { DHA) }\end{array}$ & placebo & 39 & 41 & 29.9 & 30.4 & 15.9 & 16.2 & 5 \\
\hline $\begin{array}{l}\text { Ellen L. } \\
\text { Mozurkewich } \\
2013 \text { b }\end{array}$ & $\begin{array}{l}\text { DHA-rich fish } \\
\text { oil(900 mg DHA } \\
\text { plus } 180 \mathrm{mg} \text { EPA) }\end{array}$ & placebo & 38 & 41 & 30.6 & 30.4 & 17 & 16.2 & 5 \\
\hline $\begin{array}{l}\text { Bassel H. Al } \\
\text { Wattar } 2019\end{array}$ & $\begin{array}{l}\text { high intake of } \\
\text { nuts, extra virgin } \\
\text { olive oil, fruits, } \\
\text { vegetables, } \\
\text { nonrefined grains, } \\
\text { and legumes; } \\
\text { moderate to high } \\
\text { consumption of } \\
\text { fish; low to } \\
\text { moderate intake of } \\
\text { poultry and dairy } \\
\text { products; low } \\
\text { intake of red and } \\
\text { processed meat; } \\
\text { and avoidance of } \\
\text { sugary drinks, fast } \\
\text { food, and food } \\
\text { rich in animal fat } \\
\text { versus usual care }\end{array}$ & standard care & 553 & 585 & 31.4 & 30.9 & - & - & 5 \\
\hline
\end{tabular}

\section{Pregnancy outcomes}

Compared with the control group, n-3 PUFA significantly decreased the incidence of PD (RR: 0.898, 95\%Cl: 0.819 0.984), low birthweight (RR: 0.797, 95\%Cl: $0.655 \sim 0.970$ ), and preeclampsia (RR: 0.814, 95\%Cl: $0.687 \sim 0.966$ ).

Compared with the control group, n-3 PUFA significantly increased the body weight (WMD: 99.340, 95\%Cl: 10.503 188.177 ) and body length at birth (WMD: 0.449, 95\%Cl: $0.236 \sim 0.663)$.

There was no significant difference in the incidence of PIH (RR: 0.982, 95\%Cl: $0.899 \sim 1.071$ ), IUIG (RR: 1.131, 95\%Cl: 0.957 1.337), and early PD (RR: $0.603,95 \% \mathrm{Cl}: 0.263 \sim 1.383$ ), the rate of anti-hypertensive therapy (RR: $1.070,95 \% \mathrm{Cl}$ :

$0.518 \sim 2.210$ ) and gestational diabetes (RR: $0.869,95 \% \mathrm{Cl}: 0.731 \sim 1.033$ ), and head circumference at birth (WMD: 0.295, $95 \% \mathrm{Cl}:-0.005 \sim 0.595)$ between the two groups.

The above results are presented in Fig. 2-5 and Table 2. 
Table 2

The other results of meta-analysis

\begin{tabular}{|c|c|c|c|c|c|c|c|}
\hline \multirow[t]{2}{*}{ Index } & \multirow[t]{2}{*}{ N(case/control) } & \multirow[t]{2}{*}{$\mathrm{ES}(95 \% \mathrm{Cl})$} & \multirow[t]{2}{*}{$P *$} & \multirow[t]{2}{*}{$R$} & \multirow[t]{2}{*}{$P^{\#}$} & \multicolumn{2}{|l|}{$P$ value } \\
\hline & & & & & & Begg's & Egger's \\
\hline $\begin{array}{l}\text { intrauterine growth } \\
\text { retardation IUIG }\end{array}$ & $685 / 689$ & $1.131(0.957,1.337)^{a}$ & 0.835 & $0.0 \%$ & 0.150 & 0.999 & - \\
\hline Early PD & $394 / 403$ & $0.603(0.263,1.383)^{a}$ & 0.101 & $62.7 \%$ & 0.232 & 0.999 & - \\
\hline $\begin{array}{l}\text { Anti-hypertensive } \\
\text { therapy }\end{array}$ & $550 / 574$ & $1.070(0.518,2.210)^{a}$ & 0.038 & $64.3 \%$ & 0.855 & 0.999 & 0.704 \\
\hline Gestational diabetes & $2108 / 2137$ & $0.869(0.731,1.033)^{a}$ & 0.122 & $38.6 \%$ & 0.112 & 0.999 & 0.324 \\
\hline Birth weight (g) & $2189 / 2207$ & $99.340(10.503,188.177)^{b}$ & $\dot{0} 001$ & $96.0 \%$ & 0.028 & 0.350 & 0.374 \\
\hline Birth length (cm) & $1572 / 1574$ & $0.449(0.236,0.663)^{b}$ & 0.823 & $0.0 \%$ & $<.001$ & 0.999 & 0.063 \\
\hline $\begin{array}{l}\text { Birth head } \\
\text { circumference }(\mathrm{cm})\end{array}$ & $1572 / 1574$ & $0.295(-0.005,0.595)^{b}$ & 0.052 & $54.3 \%$ & 0.054 & 0.999 & 0.508 \\
\hline \multicolumn{8}{|c|}{${ }^{\star} P$ value of Heterogeneity chi-squared } \\
\hline \multicolumn{8}{|c|}{${ }^{\#} P$ value of Pooled statistic } \\
\hline \multicolumn{8}{|l|}{${ }^{a} R R(95 \% C l)$} \\
\hline${ }^{b} W M D(95 \% C l)$ & & & & & & & \\
\hline
\end{tabular}

\section{Quality and bias assessment}

Multiple complementary methods (funnel plots, Begg's and Mazumdar's rank test, and Egger's test) were used to assess the study quality and risk of bias. The funnel plot was based on the log RR funnel plot for preeclampsia for all these studies (Fig. 6), which showed a clear symmetry, indicating a low publication bias. Besides, there still was no significant bias risk of the included studies by Begg's and Mazumdar's rank test $(Z=0.00, p=1.000)$, and Egger's test $(p=0.943)$.

\section{Discussion}

n-3 PUFA is an essential fatty acid in humans. This kind of fatty acid contains a variety of polyunsaturated fatty acids starting from the methyl end and having the first unsaturated double bond between the third and fourth carbon atoms. It mainly includes a-linolenic acid, eicosapentaenoic acid (EPA) and docosahexaenoic acid (DHA). a-linolenic acid is mainly found in vegetable oils, such as flaxseed oil and chory oil. EPA and DHA, on the other hand, are found mainly in fish oils. DHA is the most abundant polyunsaturated fatty acid in retinal photoreceptors, which is necessary to maintain the normal function of rhodopsin, and also promotes fetal brain development. EPA can reduce cholesterols and triglycerides, reduce blood viscosity, and prevent atherosclerosis and other cardiovascular diseases. Since n-3 PUFA cannot be synthesized in the human body, it must be obtained from food, and pregnancy is a period when the demand for various trace elements increases significantly, so we should eat more fish, especially deep-sea fish, to obtain sufficient n-3 PUFA.

Considering the effect of n-3 PUFA on blood lipid and cardiovascular diseases, as well as its ability to reduce inflammation, patients with diabetes are also recommended to eat more fish to increase the intake of $n-3$ PUFA. The Chinese Medical Nutrition Guidelines for Diabetes Treatment recommends that $n-3$ PUFA in the vegetable oil in the diet 
should be increased. Daily intake of $3.5 \mathrm{~g} \mathrm{n}-3$ PUFA can significantly reduce the level of TG in diabetes patients. There is no evidence to recommend whether pregnant women should take supplements of n-3 PUFA or at which specific doses, and there is some debate about the effects of n-3 supplementation. In this study, n-3 PUFA has no significant influence on the incidence of $\mathrm{PIH}$, anti-hypertensive therapy and gestational diabetes compared with the control group. Finally, meta-analysis showed no significant advantage of n-3 PUFA in reducing the incidence of gestational diabetes mellitus and hypertension.

Compared with the control group, n-3 PUFA significantly decreased the incidence of PD (RR: 0.898, 95\%Cl: 0.819 0.984), low birthweight (RR: $0.797,95 \% \mathrm{Cl}: 0.655 \sim 0.970$ ), and preeclampsia (RR: 0.814, 95\% Cl: $0.687 \sim 0.966$ ) and increased the birth weight (WMD: 99.340, 95\%Cl: $10.503 \sim 188.177$ ) and birth length (WMD: 0.449, 95\%Cl: $0.236 \sim 0.663$ ). There was no significant difference in the incidence of early PD and birth head circumference between the two groups. Maternal deficiency of n-3PUFA during pregnancy can lead to fetal growth retardation in utero, which is closely related to low birth weight. Body weight, body length and head circumference are important indicators of infant physical development. Weight can reflect recent nutritional status, body length reflects the long-term nutritional status, and head circumference reflects the development of the brain and skull. If the growth of physical development index is slow, it indicates that the nutrition and energy needed for growth and development may be insufficient. The incidence of eclampsia was reduced, and this difference was considered to be related to reduced inflammatory response by n-3 PUFA.

However, there has some limitations in the present meta-analysis; for example, the number of included RCTs was limited. The exclusion and inclusion criteria were different in different RCTs. Moreover, the results of the study were influenced by multiple factors such as the active ingredient of n-3 PUFA preparation, dosage, duration of intervention and the supplement of other nutrients in pregnant women's daily life. Finally, our analysis was based on secondary data asthe original data were not available, which precluded in-depth analyses.

In conclusion, this meta-analysis shows that n-3 PUFA is not beneficial in reducing the incidence of maternal pregnancy outcomes such as gestational diabetes mellitus and hypertension, but it is beneficial in neonatal health status.

\section{Abbreviations}

n-3 polyunsaturated fatty acid (n-3 PUFA); randomized controlled trails (RCTs); relative risk (RR); eighted mean difference (WMD); polyunsaturated fatty acids (PUFA); preterm delivery (PD); pregnancy-induced hypertension (PIH); intrauterine growth retardation (IUIG); eicosapentaenoic acid (EPA); docosahexaenoic acid (DHA)

\section{Declarations}

Ethics approval and consent to participate: Not applicable.

Consent for publication: Not applicable.

Availability of data and material: The datasets generated and analyzed during the current study are available from the corresponding author on reasonable request.

Competing interests: There is no competing interest.

Funding: No funding was received for this study.

Authors' contributions: Hong Li and Yingying Hao have made substantial contributions to conception and design of the study, written the manuscript; Xiaoshi Sun and Ningning Wen searched literature, extracted data from the collected literature and analyzed the data; Hong Li revised the manuscript; All authors approved the final version of the manuscript.

Page 9/16 


\section{References}

1. de Castro GS, et al. Dietary docosahexaenoic acid and eicosapentaenoic acid influence liver triacylglycerol and insulin resistance in rats fed a high-fructose diet. Mar Drugs. 2015;13(4):1864-81.

2. Schwingshackl L, Strasser B, Hoffmann G. Effects of monounsaturated fatty acids on glycaemic control in patients with abnormal glucose metabolism: a systematic review and meta-analysis. Ann Nutr Metab. 2011;58(4):290-6.

3. Yang ZH, Emma-Okon B, Remaley AT. Dietary marine-derived long-chain monounsaturated fatty acids and cardiovascular disease risk: a mini review. Lipids Health Dis. 2016;15(1):201.

4. Nguyen NM, et al. Maternal intake of high n-6 polyunsaturated fatty acid diet during pregnancy causes transgenerational increase in mammary cancer risk in mice. Breast Cancer Res. 2017;19(1):77.

5. Simopoulos AP. An Increase in the Omega-6/Omega-3 Fatty Acid Ratio Increases the Risk for Obesity. Nutrients. 2016;8(3):128.

6. [Expert consensus document of the diagnosis and treatment of pregnancy with heart disease]. Zhonghua Fu Chan Ke Za Zhi, 2016. 51(6): p. 401-9.

7. Jamilian $\mathrm{M}$, et al. Omega-3 fatty acid supplementation affects pregnancy outcomes in gestational diabetes: a randomized, double-blind, placebo-controlled trial. J Matern Fetal Neonatal Med. 2016;29(4):669-75.

8. Zhou SJ, et al. Fish-oil supplementation in pregnancy does not reduce the risk of gestational diabetes or preeclampsia. Am J Clin Nutr. 2012;95(6):1378-84.

9. DeGiorgio CM, Taha AY. Omega-3 fatty acids (á $\iota^{3}-3$ fatty acids) in epilepsy: animal models and human clinical trials. Expert Rev Neurother. 2016;16(10):1141-5.

10. B HAW, Dodds J. Mediterranean-style diet in pregnant women with metabolic risk factors (ESTEEM): A pragmatic multicentre randomised trial. 2019. 16(7): p. e1002857.

11. Olsen SF, et al., Randomised clinical trials of fish oil supplementation in high risk pregnancies. Fish Oil Trials In Pregnancy (FOTIP) Team. Bjog, 2000. 107(3): p. 382 - 95.

12. Smuts $\mathrm{CM}$, et al. A randomized trial of docosahexaenoic acid supplementation during the third trimester of pregnancy. Obstet Gynecol. 2003;101(3):469-79.

13. Olsen SF, Secher NJ. A possible preventive effect of low-dose fish oil on early delivery and pre-eclampsia: indications from a 50-year-old controlled trial. Br J Nutr. 1990;64(3):599-609.

14. Bulstra-Ramakers MT, Huisjes HJ, Visser GH. The effects of $3 \mathrm{~g}$ eicosapentaenoic acid daily on recurrence of intrauterine growth retardation and pregnancy induced hypertension. Br J Obstet Gynaecol. 1995;102(2):123-6.

15. Onwude $\mathrm{JL}$, et al. A randomised double blind placebo controlled trial of fish oil in high risk pregnancy. Br J Obstet Gynaecol. 1995;102(2):95-100.

16. Salvig JD, Olsen SF, Secher NJ. Effects of fish oil supplementation in late pregnancy on blood pressure: a randomised controlled trial. Br J Obstet Gynaecol. 1996;103(6):529-33.

17. D'Almeida A, et al. Effects of a combination of evening primrose oil (gamma linolenic acid) and fish oil (eicosapentaenoic + docahexaenoic acid) versus magnesium, and versus placebo in preventing pre-eclampsia. Women Health. 1992;19(2-3):117-31.

18. Kuper SG, et al. The effect of omega-3 supplementation on pregnancy outcomes by smoking status. Am J Obstet Gynecol. 2017;217(4):476. .e1-476.e6..

19. Harper $M$, et al. Omega-3 fatty acid supplementation to prevent recurrent preterm birth: a randomized controlled trial. Obstet Gynecol. 2010;115(2 Pt 1):234-42. 
20. Smuts CM, et al. High-DHA eggs: feasibility as a means to enhance circulating DHA in mother and infant. Lipids. 2003;38(4):407-14.

21. Carlson SE, et al. DHA supplementation and pregnancy outcomes. Am J Clin Nutr. 2013;97(4):808-15.

22. Mozurkewich EL, et al., The Mothers, Omega-3, and Mental Health Study: a double-blind, randomized controlled trial. Am J Obstet Gynecol, 2013. 208(4): p. 313.e1-9.

\section{Figures}

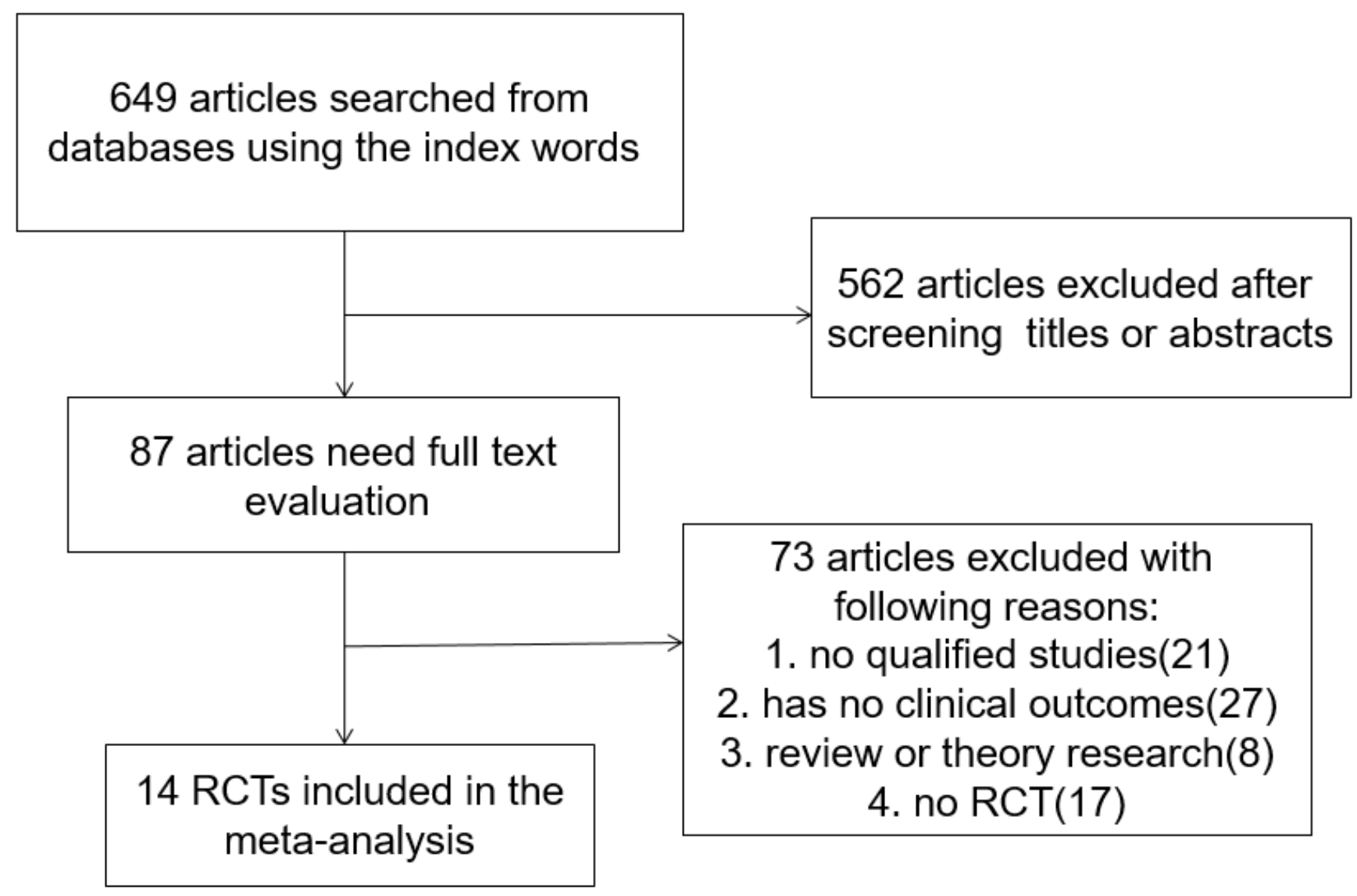

Figure 1

Literature search and selection strategy 
Study

ID

Sjrirhr F. Olsen 2000 a

Sjrirhr F. Olsen 2000 d

Cornelius M. Smuts 2003

Spencer G. Kuper 2017 a

Spencer G. Kuper 2017 b

Margaret Harper 2010

Cornelius M. Smuts 2003 a

Cornelius M. Smuts 2003 b

Cornelius M. Smuts 2003 c

Susan E Carlson 2013

Bassel H. Al Wattar 2019

Overall (I-squared $=3.6 \%, p=0.409$ )

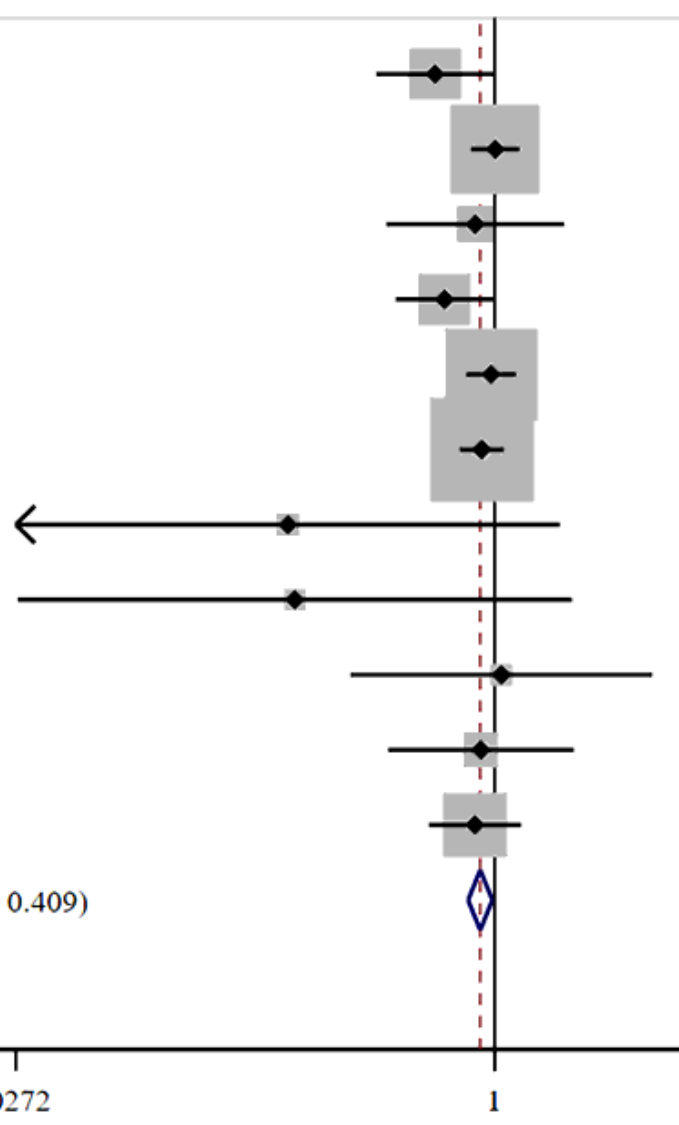

$\%$

$\mathrm{RR}(95 \% \mathrm{CI})$

Weight

$0.639(0.411,0.994)$

6.05

$1.005(0.838,1.205)$

20.38

$0.864(0.443,1.687)$

2.65

$0.686(0.476,0.989)$

6.16

$0.974(0.808,1.175)$

21.97

$0.908(0.769,1.071) \quad 28.30$

$0.211(0.027,1.637) \quad 0.78$

$0.222(0.028,1.788) \quad 0.68$

$1.053(0.339,3.272) \quad 0.69$

$0.902(0.449,1.812) \quad 2.44$

$0.863(0.610,1.221) \quad 9.91$

$0.898(0.819,0.984) \quad 100.00$

Figure 2

Forest plot for preterm delivery 
ID

$\mathrm{RR}(95 \% \mathrm{CI})$

Weight

Sjrirhr F. Olsen 2000 c

Sjrirhr F. Olsen $2000 \mathrm{~d}$

Cornelius M. Smuts 2003

Shao J Zhou 2012

Sjurdur F. Olsen 1990 a

Sjurdur F. Olsen 1990 b

Jannie Dalby Salvig 1996 a

Jannie Dalby Salvig 1996 b

Arminda D'Almeida 1992 a

Arminda D'Almeida 1992 b

Cornelius M. Smuts 2003 a

Cornelius M. Smuts 2003 b

Susan E Carlson 2013

Bassel H. Al Wattar 2019

Overall (I-squared $=25.9 \%, p=0.176$ )

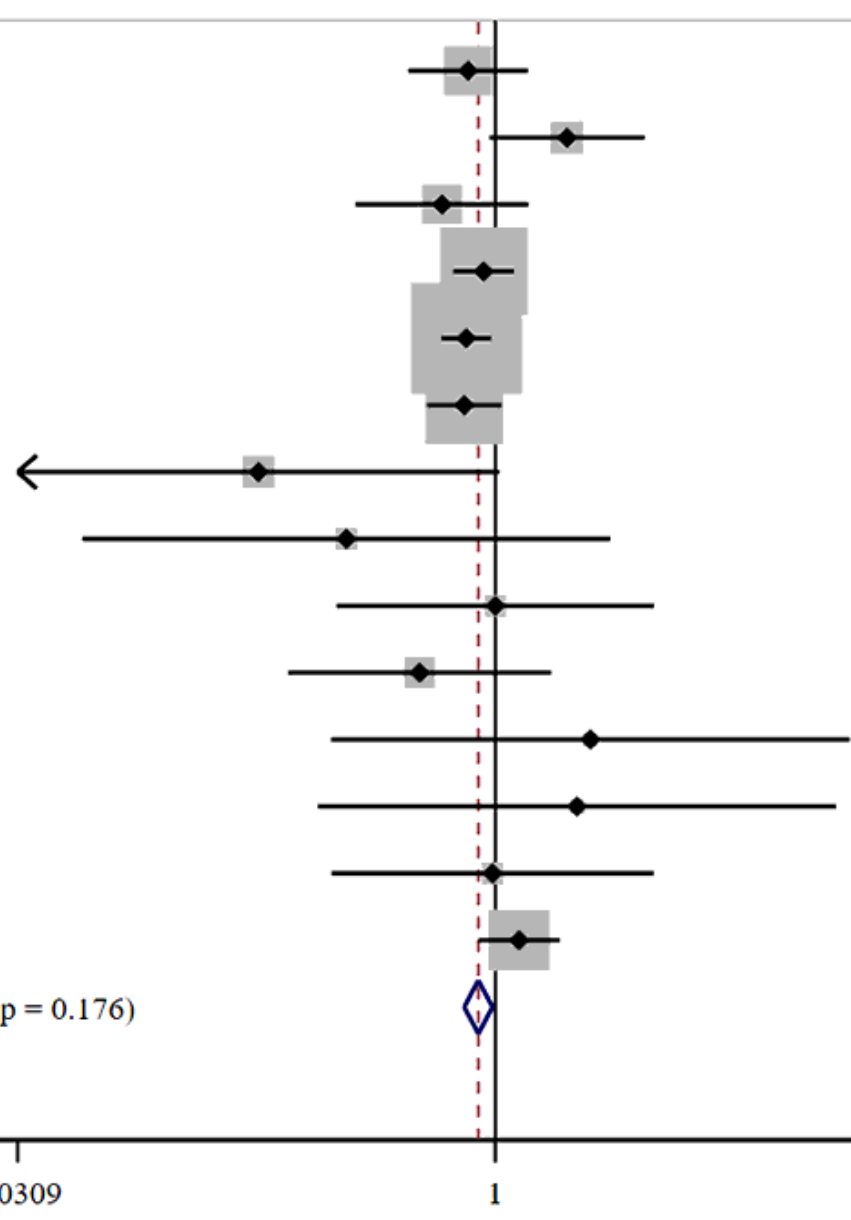

$0.719(0.348,1.487)$

5.79

$2.381(0.930,6.095)$

2.14

$0.525(0.184,1.497)$

3.51

$0.868(0.602,1.252)$

21.18

$0.703(0.521,0.949)$

35.09

$0.687(0.439,1.074)$

16.39

$0.057(0.003,1.051)$

2.14

$0.165(0.007,4.018)$

0.72

$1.000(0.147,6.823)$

0.72

$0.400(0.081,1.966)$

1.80

$3.158(0.137,72.844)$

0.18

$2.684(0.117,61.584)$

0.19

$0.966(0.138,6.783)$

0.73

$1.335(0.816,2.182)$

9.43

$0.814(0.687,0.966)$

100.00

\section{Figure 3}

Forest plot for preeclampsia 


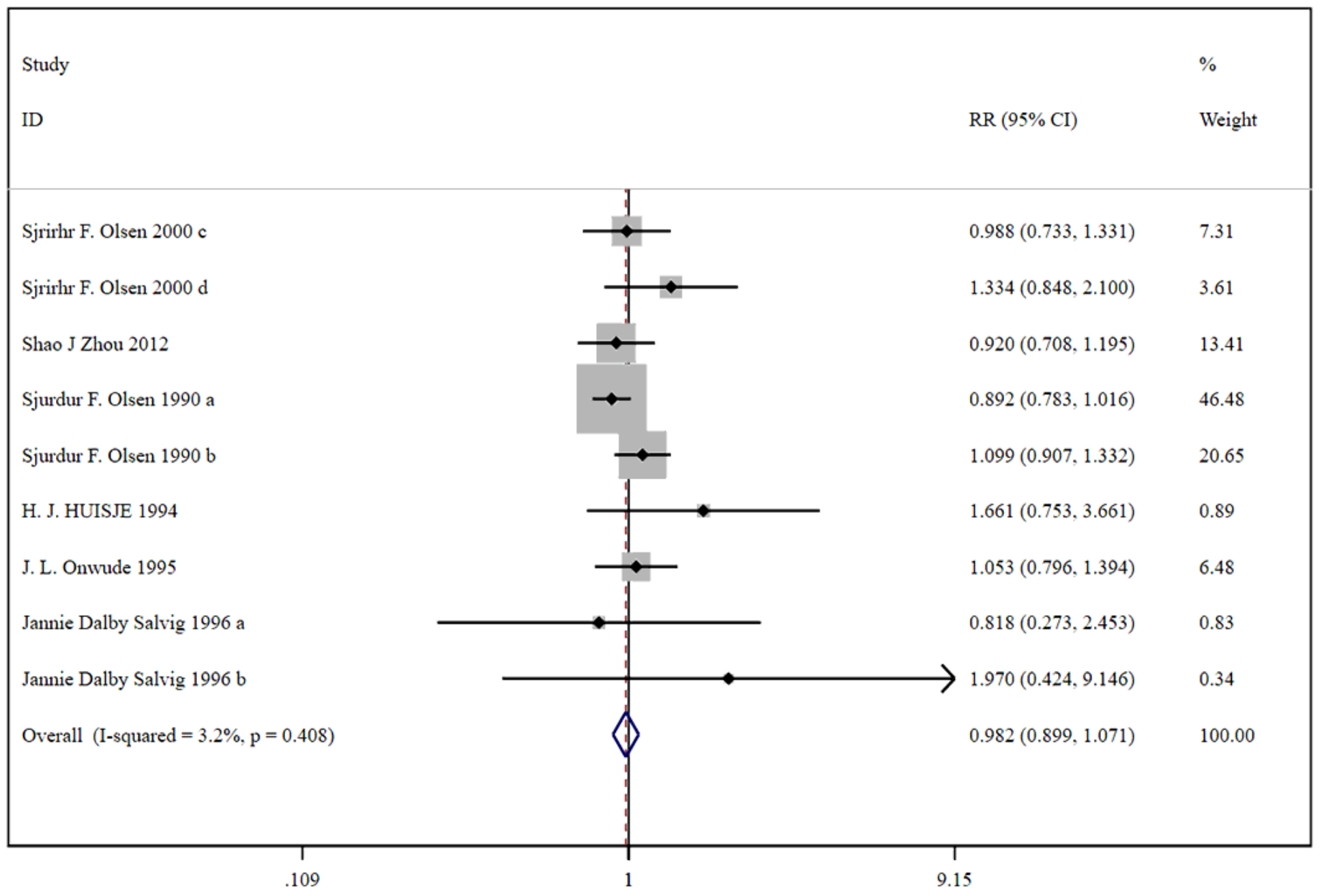

Figure 4

Forest plot for pregnancy induced hypertension 


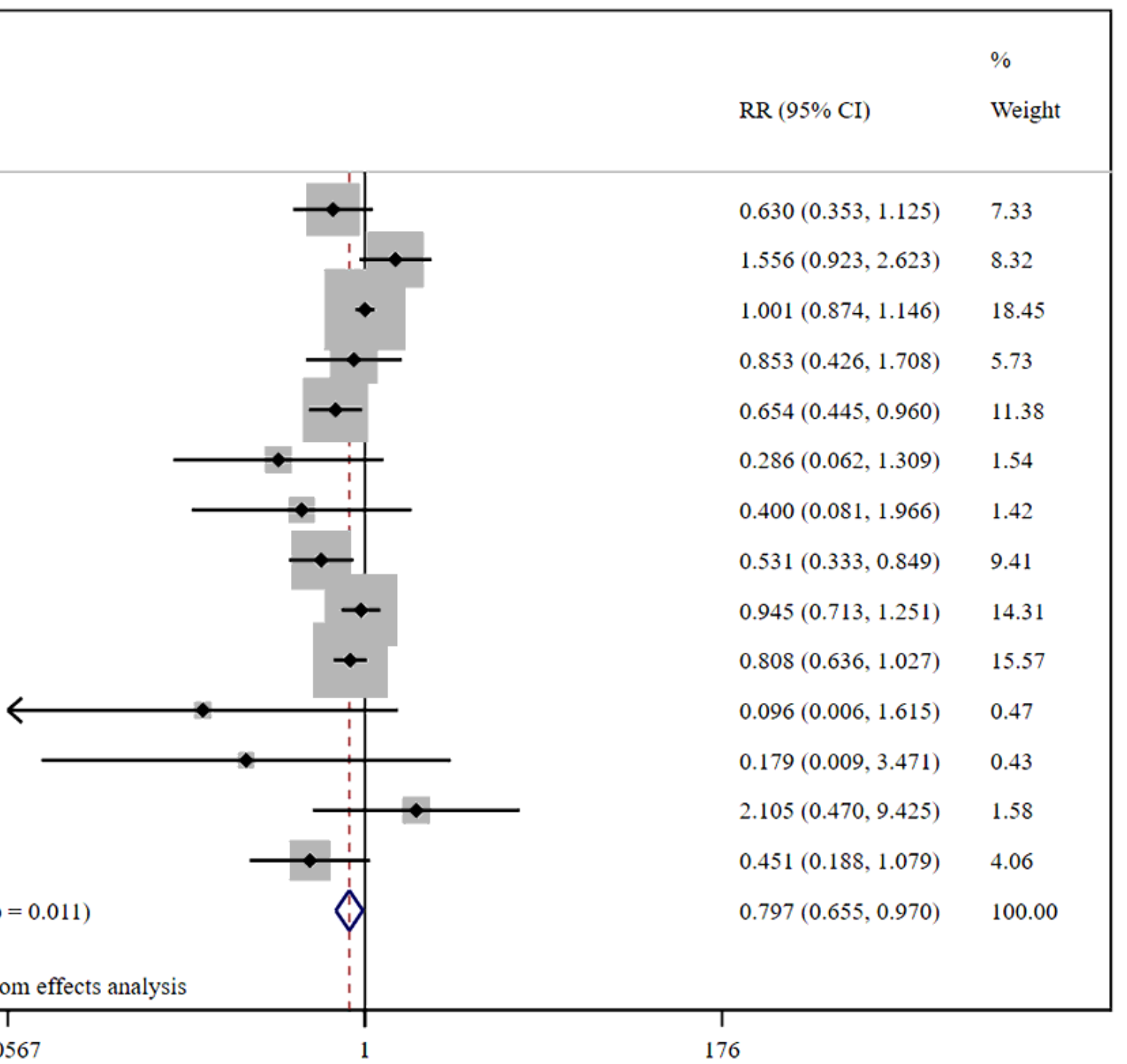

Sjrirhr F. Olsen 2000 a

Sjrirhr F. Olsen 2000 b

Sjrirhr F. Olsen $2000 \mathrm{~d}$

Cornelius M. Smuts 2003

Shao J Zhou 2012

Arminda D'Almeida 1992 a

Arminda D'Almeida 1992 b

Spencer G. Kuper 2017 a

Spencer G. Kuper 2017 b

Margaret Harper 2010

Cornelius M. Smuts 2003 a

Cornelius M. Smuts 2003 b

Cornelius M. Smuts 2003 c

Susan E Carlson 2013

Overall $(\mathrm{I}$-squared $=52.3 \%, \mathrm{p}=0.011$

NOTE: Weights are from random effects analysis

.00567

176

\section{Figure 5}

Forest plot for low birthweight 


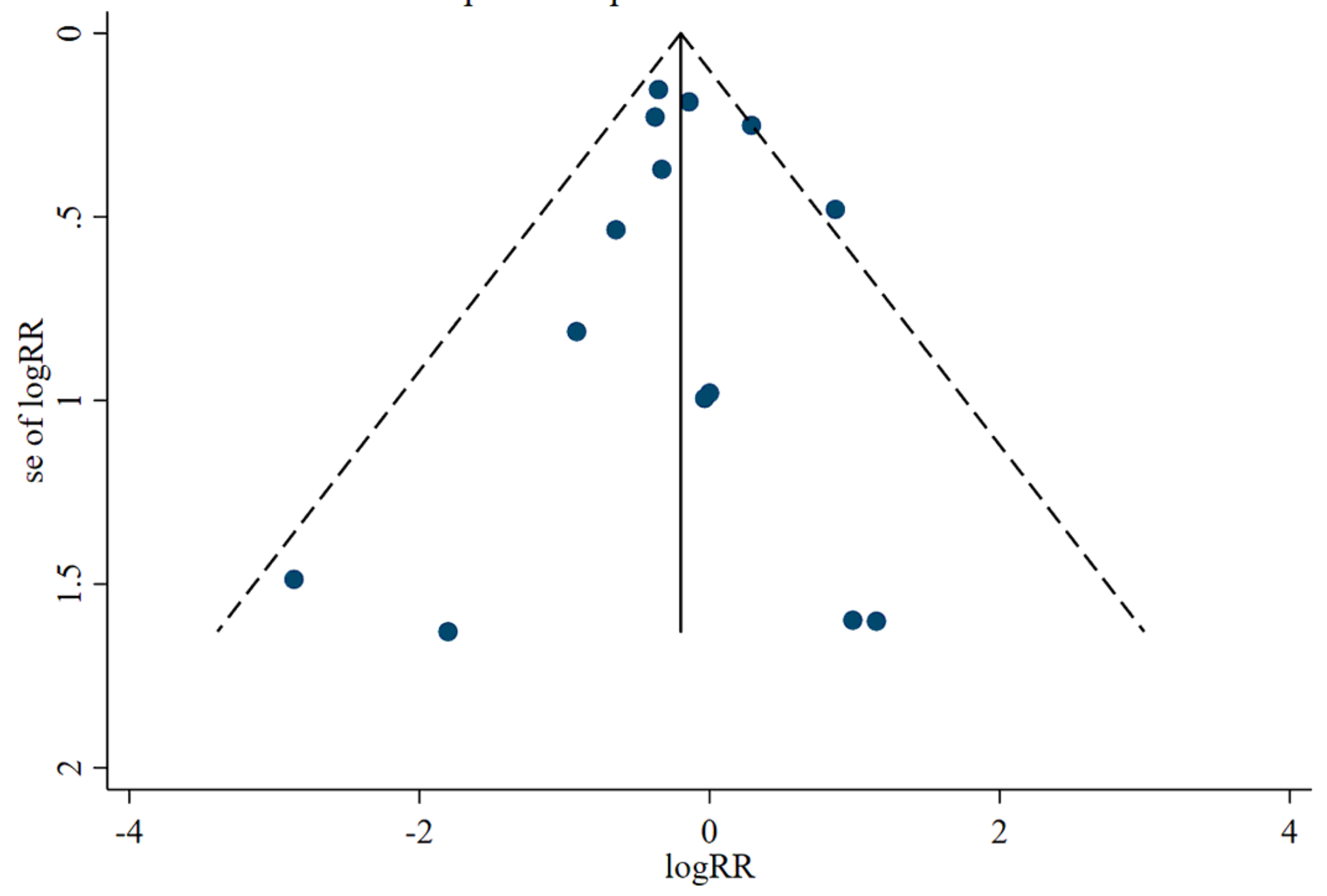

Figure 6

Funnel plot of the included studies 